\title{
POOPERACINIO SKAUSMO MALŠINIMO METODŲ ITAKA ANKSTYVAI KELIO SĄNARIO FUNKCIJAI, LETTINIAM SKAUSMUI IR GYVENIMO KOKYBEI PO PILNO KELIO SĄNARIO ENDOPROTEZAVIMO OPERACIJOS
}

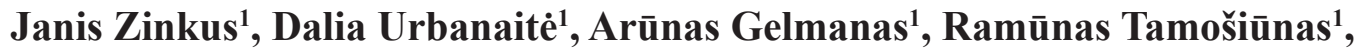 \\ Arūnas Vertelis ${ }^{2}$, Andrius Macas ${ }^{1}$ \\ ${ }^{1}$ Lietuvos sveikatos mokslu universiteto ligoniné Kauno klinikos, Anesteziologijos klinika, \\ ${ }^{2}$ Lietuvos sveikatos mokslu universiteto ligoniné Kauno klinikos, \\ Ortopedijos-traumatologijos klinika
}

Raktažodžiai: pooperacinis skausmas, tęstinè juosmeninio rezginio blokada, tęstinè vidusąnarinè blokada, pilna kelio sąnario endoprotezavimo operacija, lètinis skausmas, gyvenimo kokybè.

\begin{abstract}
Santrauka
Pilna kelio sąnario endoportezavimo (PKSE) operacija - viena iš dažniausiai pasaulyje atliekamų ortopedinių operacijų, sąlygojančių lètinio pooperacinio skausmo išsivystymą [1-3], kuris turi ịtakos pacientų gyvenimo kokybei. Skausmo malšinimas po šiu operacijų yra tikras iššūkis gydančiajam personalui visame pasaulyje [1-8]. Paprastai taikoma multimodalinè analgezija, kuri apima ịvairius nuskausminimo metodus, pvz.: intraveniniai opioidai, periferinių nervų blokados, epidurinè analgezija, vidusąnarinès blokados, peroraliniai analgetikai ir kt. [1, 2]. Tačiau "auksinio standarto" vis dar nèra. Mūsų tyrimo tikslas buvo išsiaiškinti ūmaus pooperacinio skausmo malšinimo metodo, taikyto po pilno kelio sąnario endoprotezavimo (PKSE) operacijos, ittaką pacientu gyvenimo kokybei bei vèlyvam pooperaciniam skausmo atsiradimui po PKSE operacijų. Buvo atliktas perspektyvinis tyrimas, ị kuri ịtraukti 54 pacientai, kuriems atliktos PKSE operacijos. Pagal operacijos dieną atliktą randomizaciją, pacientai buvo suskirstyti ị dvi lygias grupes: I grupę (taikyta juomeninio rezginio blokada) ir II grupę (taikyta vidusąnarinè blokada). Kelio sąnario funkcija bei lètinio skausmo (LS) įtaka gyvenimo kokybei vertinta pagal VAS skalę ir specialu KOOS (ang. Knee injury and osteoarthritis outcome score) klausimyną
\end{abstract}

bei prieš operaciją pildytą Yesavage'o geriatrinès depresijos skalès anketą. Tyrimo rezultatai parodè, jog pooperacinis nuskausminimo metodas neturejjo itakos LS išsivystymui, o depresija galejjo sąlygoti lètinị pooperacinį skausmą. Kelio sąnario funkcija II grupès pacientams per pirmą mėnesị po PKSE operacijos gerejo greičiau. Gyvenimo kokybè, nepaisant galimos depresijos, reikšmingai pagerejjo abiejų grupių pacientams.

\section{İvadas}

Adekvatus pooperacinio skausmo malšinimas - būtina sąlyga po PKSE operacijų [1-8], kadangi tai sąlygoja geresnius chirurginio gydymo rezultatus, efektyvią ankstyvają reabilitaciją ir greitesnị kelio sąnario funkcijos atsistatymą, geresnę pacientų gyvenimo kokybę bei gali užkirsti kelią lètinio skausmo sindromo išsivystymui [2-4]. Nesant nutarimo, koks pooperacinio skausmo malšinimo metodas yra geriausias, paprastai taikoma multimodalinè analgezija $[2,3,5]$, pvz.: regioninis pooperacinis nuskausminimas (tęstinis epidūrinis, tęstinè juosmeninio rezginio blokada, vidusąnarinė blokada ar kt.) ir sisteminé analgezija. Vis dèlto, praktikoje pastebėta, kad po PKSE operacijų didžiausias vaidmuo pooperaciniu periodu tenka regioninei analgezijai [9].

Tęstinè juosmeninio rezginio blokada pradedama PKSE operacijos pabaigoje per specialiai ịleistą juosmeninio rezginio kateterį. Yra dvi kateterio ịleidimo metodikos - užpakalinis ,psoas“" metodas ir priekinis n. femoralis 3-in-1 ("trys viename") blokados metodas. Pooperacinei analgezijai taikoma vietinio anestetiko ir narkotinio analgetiko mišinio infuzija automatine švirkštine pompa. Taip 
yra užtikrinama vienpusė efektyvi analgezija. Tačiau taikant šį skausmo malšinimo metodą, ankstyvuoju pooperaciniu periodu dažnai pasitaiko operuotos pusès keturgalvio raumens silpnumas [7], kuris gali sąlygoti pooperacines traumas $[2,7]$.

Kitas alternatyvus pooperacinio skausmo malšinimo metodas - vidusąnarinè blokada [3-5, 7]. Specialus kateteris ị sąnario kapsulę įleidžiamas operacijos pabaigoje. Per

1 lentelè. Atrankos kriterijai

\begin{tabular}{|l|l|}
\hline \multicolumn{1}{|c|}{ Ittraukimo kriterijai } & \multicolumn{1}{c|}{ Atmetimo kriterijai } \\
\hline - Informuotą paciento sutiki- & - Nesutinkantys dalyvauti tyrime; \\
mą pasirašę asmenys; & - ASA III - V klasė; \\
- ASA I-II klasė; & - Kepenų ir inkstų funkcijos nepakanka- \\
- Vyresni nei 18 metų am- & mumas; \\
žiaus asmenys, turintys vieno- & - Nutukimas (KMI> $\left.40 \mathrm{~kg} / \mathrm{m}^{2}\right) ;$ \\
dą pirminès kelio osteoartrozės & - Neuropatinis skausmas, insultas ir neu- \\
laipsnị, kuriems planuojama & rologinis deficitas po jo, galūnių sensorikos \\
pilna kelio sąnario endopro- & ir/ar motorikos sutrikimai; \\
tezavimo operacija LSMUL & - Nesugebejjimas savarankiškai vaikščioti; \\
Kauno klinikose. & - Alergija vietiniams anestetikams ir tyri- \\
& me naudojamiems vaistams; \\
& - Nesugebantys suprasti studijos protokolo \\
& reikalavimų (psichikos sutrikimai). \\
\hline
\end{tabular}

2 lentelè. Multimodalinė pooperacinè analgezija

\begin{tabular}{|c|c|c|c|}
\hline & $\begin{array}{l}\text { Nuskausminimas } \\
72 \text { val. po operacijos }\end{array}$ & $\begin{array}{l}\text { nu- } \\
\text { as } 72 \\
\text { cijos }\end{array}$ & $\begin{array}{r}\text { Papildon } \\
\text { mi } \\
\text { (VAS }\end{array}$ \\
\hline 范 & $\begin{array}{l}50 \mathrm{ml} 0,125 \text { proc. } \\
\text { bupivakaino tirpalo } \\
\text { ir fentanilio } 5 \mu \mathrm{g} / \mathrm{ml} \\
\text { infuzija } 7-12 \mathrm{ml} / \mathrm{val} \text {. } \\
\text { i JRK. }\end{array}$ & $\begin{array}{l}\text { - Nesteroidi } \\
\text { vaistai nuo u } \\
\text { gimo (Naclof }\end{array}$ & $\begin{array}{l}\text { - } 10-15 \mathrm{ml} 0,125 \text { proc. } \\
\text { bupivakaino tirpalo ir } \\
\text { fentanilio } 5 \mu \mathrm{g} / \mathrm{ml} \text { miši- } \\
\text { nio bolus dozè. } \\
\text { - Morfino pompa pa- }\end{array}$ \\
\hline$\stackrel{\mathscr{E}}{\overparen{E}}$ & $\begin{array}{l}50 \mathrm{ml} 0,125 \text { proc. } \\
\text { bupivakaino tirpalo } \\
\text { ir fentanilio } 5 \mu \mathrm{g} / \mathrm{ml} \\
\text { infuzija } 7-12 \mathrm{ml} / \mathrm{val} \text {. } \\
\text { i VK. }\end{array}$ & $\begin{array}{l}150 \mathrm{mg} / \text { parą i veną } \\
\text { kas } 24 \text { val.) } \\
\text { - Acetaminofenas } \\
1 \text { g kas } 6 \text { val. }\end{array}$ & $\begin{array}{l}\text { ciento kontroliuojamai } \\
\text { analgezijai (PKA): pa- } \\
\text { vienèmis morfino dozé- } \\
\text { mis po } 1 \mathrm{mg} \text { su } 7 \text { min. } \\
\text { atidejimais, be foninès } \\
\text { infuzijos. }\end{array}$ \\
\hline
\end{tabular}

3 lentelè. Pacientų demografiniai duomenys

\begin{tabular}{|l|l|c|c|}
\hline \multicolumn{2}{|c|}{ Požymis } & I grupe், n=27 & II grupe், n=27 \\
\hline \multirow{2}{*}{ Lytis } & Vyrai & $11(40,7 \%)$ & $2(7,4 \%)$ \\
\cline { 2 - 4 } & Moterys & $16(59,3 \%)$ & $25(92,6 \%)$ \\
\hline \multirow{2}{*}{ Amžius (metai) } & $70,41 \pm 7,551$ & $66,85 \pm 7,690$ \\
\hline KMI (kg/m $)$ & $29,38 \pm 4,56$ & $30 \pm 3,73$ \\
\hline \multirow{2}{*}{$\begin{array}{l}\text { Ügis } \\
\text { (cm) }\end{array}$} & Vyrai & $167,18 \pm 4,143$ & $166,5 \pm 2,121$ \\
\cline { 2 - 4 } & Moterys & $161,44 \pm 4,195$ & $165,28 \pm 5,884$ \\
\hline $\begin{array}{l}\text { Svoris } \\
\text { (kg) }\end{array}$ & Vyrai & $79,55 \pm 11,121$ & $83 \pm 2,828$ \\
\cline { 2 - 4 } & Moterys & $78,63 \pm 15,624$ & $81,88 \pm 10,430$ \\
\hline
\end{tabular}

ši kateteri pooperaciniu periodu taip pat taikoma vietinio anestetiko ir narkotinio analgetiko mišinio infuzija automatine švirkštine pompa. Šis nuskausminimo metodas yra labai paprastas: veikia tik ị chirurginès intervencijos sritị. Be to, teigiama, kad padeda išvengti komplikacijų (raumenų silpnumas), susijusių su nervų bloku, nervų pažaidos, tačiau neapsaugo nuo vietinès infekcijos kateterio įleidimo vietoje $[5,7]$.

Šio darbo tikslas buvo palyginti tęstinių juosmeninio rezginio ir vidusąnarinès blokadų efektyvumo, malšinant ūmų pooperacinị skausmą po PKSE operacijos, ittaką pacientų gyvenimo kokybei bei LS išsivystymui po PKSE operacijos.

\section{Tyrimo metodika}

Gavus LSMU Bioetikos centro leidimą, Lietuvos sveikatos mokslų universiteto ligoninès Kauno klinikų Ortopedijos - traumatologijos klinikoje (LSMUL KK OTK) atliktas prospektyvinis randomizuotas tyrimas. Vadovaujantis atrankos kriterijais (1 lentelè), i tyrimą itraukti 54 pacientai, kuriems buvo atlikta PKSE operacija.

Pagal operacijos dieną akluoju metodu priskirtą pooperacinio nuskausminimo metodą (voko traukimo būdu), tiriamieji buvo suskirstyti i dvi lygias grupes: pirmai grupei taikyta juosmeninio rezginio blokada "trys viename" su tęstine infuzija per periferinių nervų blokadai skirtą kateterị. Antrai grupei taikyta vidusąnarinè blokada su tęstine infuzija per žaizdos infiltracinị kateterị.

Anestezijos metodika: atvykus i operacinę, taikant standartinę gyvybinių funkcijų stebėseną (arterinio kraujo spaudimas, širdies susitraukimo dažnis, pulsoksimetrija), pacientams skirta $500 \mathrm{ml}$ izotoninio natrio chlorido tirpalo intraveniné infuzija. Abiejų grupių tiriamiesiems operaciniam nuskausminimui buvo atlikta spinalinè nejautra ( $\mathrm{L}_{3-4}$ subarachnoidinị tarpą suleista $3 \mathrm{ml} \mathrm{0,5}$ proc. (15 mg) bupivakaino tirpalo). Pirmai grupei papildomai ileistas juosmeninio rezginio kateteris atlikus spinalinę nejautrą iki operacijos pradžios. Antrai grupei vidusąnarinis kateteris ịleistas operuojančio ortopedo-traumatologo operacijos pabaigoje. Anestezijos metu taikyta infuzoterapija kristaloidiniais tirpalais $8-10 \mathrm{ml} / \mathrm{kg} /$ val. Sedacijai skirta $20 \mathrm{ml} 1$ proc. propofolio infuzija (1-2 $\mathrm{mg} / \mathrm{kg} / \mathrm{val}$. greičiu).

Pooperacinès regioninès analgezijos metodikos: 
4 lentelè. Kelio lenkimo laipsniai pasyvaus ir aktyvaus lenkimo metu

\begin{tabular}{|c|c|c|c|c|c|c|}
\hline & \multicolumn{2}{|c|}{$\begin{array}{c}\text { Maksimalus pasyvus lenkimas } \\
\text { (laipsniais) }\end{array}$} & \multirow[t]{2}{*}{$\mathbf{P}$} & \multicolumn{2}{|c|}{$\begin{array}{c}\text { Maksimalus aktyvus lenkimas } \\
\text { (laipsniais) }\end{array}$} & \multirow[t]{2}{*}{$\mathbf{P}$} \\
\hline & I grupè & II grupė & & I grupè & II grupė & \\
\hline Prieš operaciją & $111,78 \pm 11,015$ & $116,96 \pm 10,357$ & 0,081 & $117,93 \pm 11,142$ & $124,41 \pm 9,005$ & 0,023 \\
\hline 7 parą po operacijos & $92,74 \pm 6,478$ & $96,07 \pm 6,038$ & 0,056 & $95,56 \pm 7,282$ & $99,22 \pm 5,989$ & 0,048 \\
\hline 1 mėnesị po operacijos & $110,41 \pm 13,910$ & $117,89 \pm 10,308$ & 0,029 & $114,15 \pm 14,365$ & $122,93 \pm 11,479$ & 0,016 \\
\hline
\end{tabular}

5 lentelè. Depresija pooperaciniu periodu

*Yesavage'o geriatrinès depresijos skalès klausimyna užpildè 46 (85 proc.) iš 54 pacientu.

\begin{tabular}{|l|l|l|l|}
\hline & $\begin{array}{c}\text { Nẻra de- } \\
\text { presijos } \\
(<\mathbf{5} \text { balai) }\end{array}$ & $\begin{array}{c}\text { Galima depre- } \\
\text { sija } \\
(\mathbf{5 - 1 0} \text { balų) }\end{array}$ & $\begin{array}{c}\text { Yra depresija } \\
(\geq \mathbf{5} \text { balai) }\end{array}$ \\
\hline I grupe் & $10(50 \%)$ & $9(45 \%)$ & $1(5 \%)$ \\
\hline II grupè & $11(42,3 \%)$ & $10(38,5 \%)$ & $5(19,2 \%)$ \\
\hline
\end{tabular}

1. Juosmeninio rezginio kateterio (JRK) illeidimas ir tęstinė juosmeninio rezginio blokada. Visi JRK pirmos grupès pacientams ịleisti spinalinès anestezijos metu vieno tyrëjo. Aseptinèmis sąlygomis buvo atliekama juosmeninio rezginio nervų blokada "trys viename": pacientui, gulinčiam ant nugaros su ištiesta ir $15^{\circ}$ kampu i išorę pasukta koja, $3 \mathrm{~cm}$ žemiau kirkšnies raiščio ir 1-1,5 cm ị išorę nuo šlauninès arterijos $45^{0}$ kampu durta su 18 G Tuohy tipo
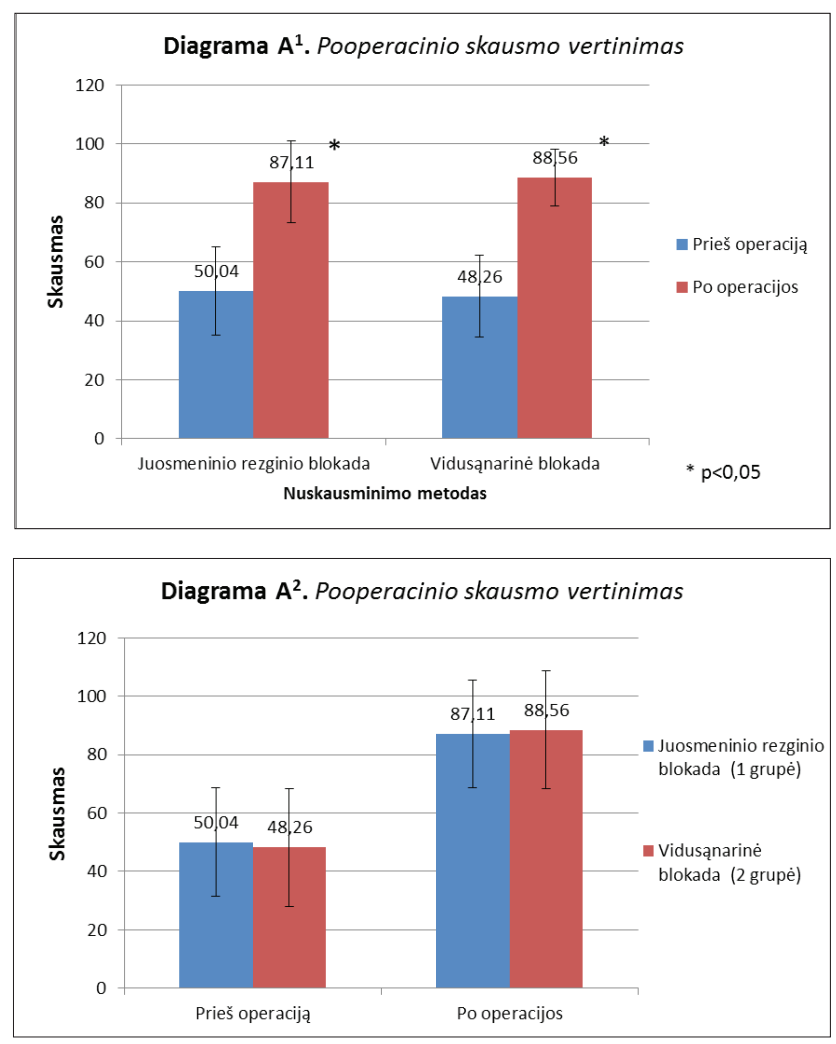

adata, sujungta su neurostimuliatoriumi (adatos smaigalys nukreiptas kranialine kryptimi). Gavus keturgalvio šlaunies raumens atsaką i neurostimuliatoriaus impulsą, atlikus aspiracijos mèginį bei distaliau dūrimo vietos delnu užspaudus fascijinę makštį, siekiant praplèsti tarpfascijinį tarpą, sušvirkšta 25-30 ml fiziologinio tirpalo (lengvesniam JRK ivedimui). Ivedus $20 \mathrm{G}$ JRK iki $15-20 \mathrm{~cm}$ gylio, siekiant išvengti galimos kateterio dislokacijos, šis buvo tunelizuotas 5-7 cm po oda nuo dūrio vietos. Operacijos pabaigoje i JRK suleista $30 \mathrm{ml} \mathrm{0,25}$ proc. bupivakaino tirpalo ir po to

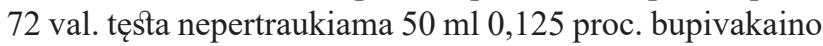
tirpalo ir fentanilio $5 \mu \mathrm{g} / \mathrm{ml}$ infuzija.

2. Vidusąnarinio kateterio (VK) įleidimas ir tęstinè vidusąnarinè blokada. Antros grupès pacientams kelio są-

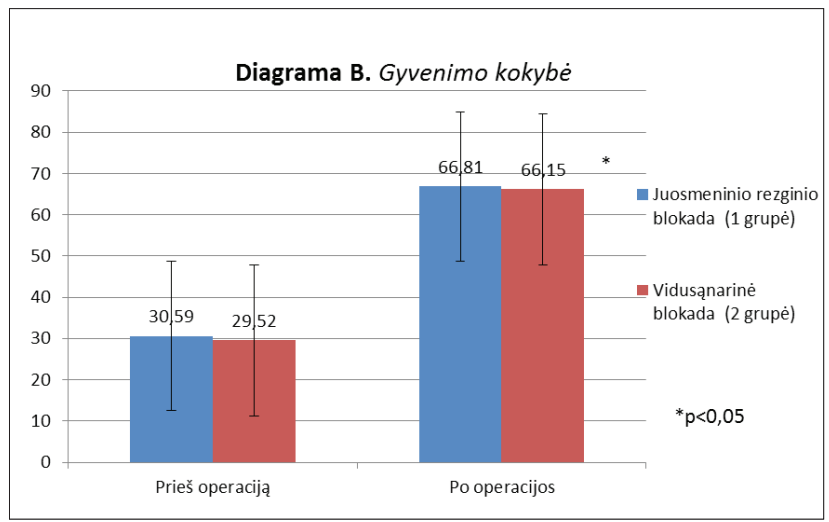

Diagrama C ${ }^{1}$. Skausmas, atliekant pasyvy maksimaly lenkimq

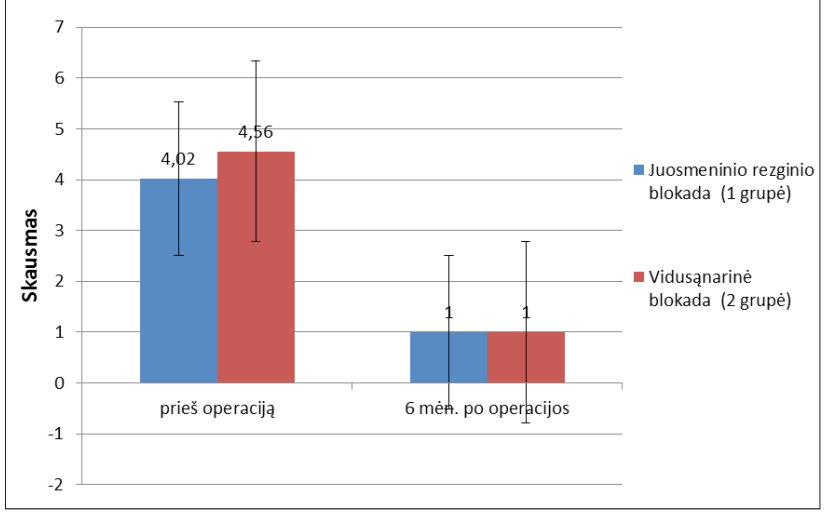


nario audiniai buvo infiltruoti tirpalu, susidedančiu iš 150 mg bupivakaino ( $120 \mathrm{ml} \mathrm{-} \mathrm{0,125} \mathrm{proc.)} \mathrm{ir} \mathrm{0,2} \mathrm{mg}$ epinefrino (tirpalas buvo leidžiamas ị užpakalinę kapsulę, priekinès kapsulès likutį, keturgalvio raumens sausgyslę, girnelès raištị ir minkštuosius audinius, supančius sąnarị). Operacijos pabaigoje į sąnario kapsulę, prie keturgalvio raumens sausgyslès, girnelès raiščio ir minkštujų audinių, supančių sąnarị, buvo įleistas specialus VK. Per ši kateteri 72 val. po operacijos buvo skiriama nepertraukiama $50 \mathrm{ml} \mathrm{0,125}$ proc. bupivakaino tirpalo ir fentanilio $5 \mu \mathrm{g} / \mathrm{m}$ infuzija (7 $12 \mathrm{ml} /$ val. greičiu).

Po PKSE operacijų 15 - 20 proc. pacientu gali pasireikšti pakinklio srities skausmas $[1,2]$. Todèl abiejų grupių tiriamiesiems, siekiant išvengti šio nepageidaujamo poveikio, operuojantysis ortopedas - traumatologas PKSE operacijos pabaigoje atliko kelio sąnario užpakalinès kapsulès infiltraciją tirpalu, susidedančiu iš $50 \mathrm{mg}$ bupivakaino (40 $\mathrm{ml}-0,125$ proc.) ir 0,2 mg epinefrino.

Vieną parą po atliktos PKSE operacijos tiriamieji buvo stebimi poanestezineje intensyvaus sekimo palatoje (ISP). Monitoruotos gyvybinès funkcijos, taikyta infuzoterapija, profilaktinè antibiotikoterapija, stresinių opu profilaktika, tromboembolijų profilaktinès priemonès, esant anemijai
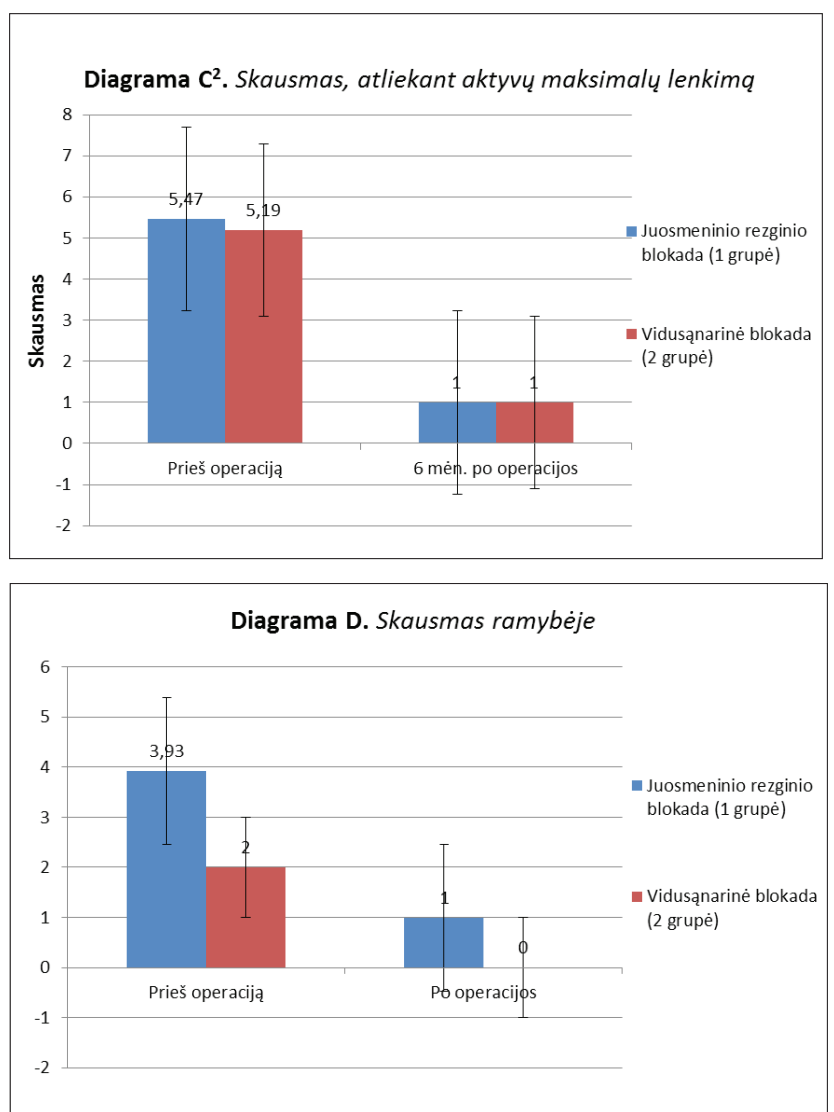

- kraujo produktų transfuzijos, simptominis gydymas. Pasireiškus pooperaciniam pykinimui ir vėmimui, skirta 2-4 mg ondansetrono ị veną.

Visiems pacientams ISP buvo pradèta multimodalinè pooperacinè analgezija (2 lentelè).

Pooperacinio skausmo malšinimo metodai buvo vertinami tyrimą atliekančio tyrejjo (anesteziologo) pagal VAS skalę (kelio lenkimo metu ir ramybeje) 3, 6, 24 valandą po operacijos nuo atvykimo i ISP pradžios. Analogiškai buvo vertinama motorinè blokada bei sedacijos laipsnis, pykinimas, vèmimas ir kiti pašaliniai reiškiniai.

Išvykusius iš ISP i skyriaus palatą, pacientai toliau buvo lankomi tyrejo. Kasdien sekimo lape registruota: kelio skausmas lenkimo metu ir ramybeje (pagal VAS skalę), kelio sąnario funkcija (2 MĖT), vertinama motorinè blokada, sedacijos laipsnis, širdies susitraukimų dažnis, arterinis kraujo spaudimas, morfino sunaudojimas 48 ir 72 val. bei 7 parą po operacijos.

Kelio sąnario funkcija bei LS įtaka gyvenimo kokybei vertinta pagal VAS skalę ir specialų KOOS (ang. Knee injury and osteoarthritis outcome score) klausimyną bei prieš operaciją pildytą Yesavage'o geriatrinès depresijos skalès anketą.

Duomenys apdoroti IBM SPSS 22.0 programa. Kategorinių požymių palyginimui taikytas chi kvadrato kriterijus $\left(\chi^{2}\right)$. Kiekybinių požymių palyginimui taikytas parametrinis T testas, neparametrinis Mann-Whitney U testas nepriklausomoms imtims. Kokybiniai požymiai lyginti KruskalWallis testu, taikyta kartotinų matavimų dispersinè analizè. Pateikiama aprašomoji analizè. Duomenys vertinti kaip statistiškai reikšmingi, kai $\mathrm{p}<0,05$.

\section{Rezultatai}

Tyrime dalyvavę 54 asmenys buvo suskirstyti į dvi grupes po 27 žmones. Pacientai savo grupèse buvo panašaus amžiaus, ūgio, svorio, KMI (3 lentelè).

Pagal KOOS, abiejose tiriamosiose grupèse poope-

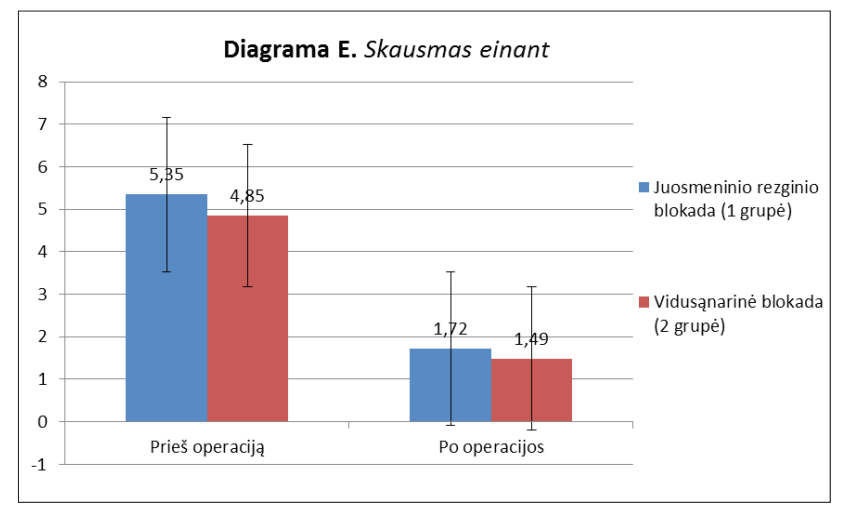


racinis skausmo vertinimas buvo reikšmingai mažesnis $(p<0,05)$ (diagrama $\left.\mathrm{A}^{1}\right)$, tačiau tiek prieš PKSE operaciją, tiek po jos tarp grupių reikšmingo skirtumo nenustatyta (diagrama $\mathrm{A}^{2}$ ). Gyvenimo kokybe po operacijos statistiškai reikšmingai pagerejo abiejose grupèse $(p<0,05)$, o lyginant tarp grupių patikimo skirtumo nebuvo (diagrama B).

Vertinant kelio sąnario funkciją, pasyvus maksimalus lenkimas per kelio sąnarį tarp tiriamų grupių skyrèsi praèjus tik 1 ménesiui po operacijos $(\mathrm{p}=0,029)$. Aktyvus maksimalus lenkimas per kelio sąnari tarp grupių reikšmingai skyrèsi prieš PKSE operaciją $(\mathrm{p}=0,023)$ bei septintą parą $(\mathrm{p}=0,048)$ ir pirmą mènesi po jos $(\mathrm{p}=0,016)$ (4 lentelè). Subjektyvus skausmas šių judesių metu vertinant pagal VAS skalę tiek prieš PKSE operaciją, tiek praejjus pusei metų po jos statistiškai reikšmingai tarp grupių nesiskyre (diagra$\operatorname{mos} \mathrm{C}^{1}$ ir $\mathrm{C}^{2}$ ).

II grupeje prieš PKSE operaciją ramybejje registruotas reikšmingai mažesnis kelio sąnario skausmas. Pooperacinio nuskausminimo metodas statistiškai patikimai efektyvesnis taip pat buvo II grupés pacientams $(p<0,05)$ (diagrama D). Lyginant su priešoperacine būkle, skausmas einant po PKSE operacijos abiejose grupèse reikšmingai sumažèjo, tačiau tarp grupių statistiškai patikimai nesiskyrè (diagrama E).

Vertinant pacientų gyvenimo kokybę pooperaciniu laikotarpiu, pusei I grupès bei 57,7 proc. II grupès pacientu pooperacini skausmą galèjo sąlygoti depresiją (5 lentelè), tačiau statistiškai reikšmingo skirtumo tarp grupių nebuvo $(\mathrm{p}>0,05)$.

\section{Diskusija}

Esant pakankamai skausmo kontrolei pooperaciniu periodu, pagerejja pacientų pasitenkinimas, reabilitacija tampa lengvesnè, o hospitalizacijos laikas trumpejja $[1,2]$. Be to, ankstyvoji reabilitacija gali sumažinti komplikacijų, tokių kaip giliujų venų trombozè, plaučių arterijos embolija, pneumonija, šlapimo susilaikymas, artrofibrozè, riziką, taip pagerinant pacientų gyvenimo kokybę [1].

Kovalak ir kt. teigia [1], kad tokios komplikacijos, kaip artrofibrozè, galima išvengti, jeigu maksimalus lenkimas per kelio sąnarị ankstyvuoju pooperaciniu periodu atsistato greičiau. Savo studijoje jie lygino juosmeninio rezginio blokados bei periartrikulinių injekcijų efektyvumą. Anot tyrimo rezultatu, pooperaciniu periodu geresnis pasyvus bei aktyvus lenkimas per kelio sąnarị buvo juosmeninio rezginio blokados grupejje, tačiau skausmą po PKSE operacijos aktyvių judesių metu pacientai šioje grupeje jautė stipresnį. Remiantis mūsų tyrimo rezultatais, abiejose grupèse tiek pasyvus maksimalus lenkimas, tiek aktyvus maksimalus lenkimas neišprovokavo reikšmingo skausmo skir- tumo tarp grupių nei prieš operaciją, nei po jos. O aktyvus maksimalus lenkimas po operacijos buvo geresnis pacientų, kuriems buvo taikyta vidusąnarinè blokada.

Taip pat autoriai konstatuoja [1], kad juosmeninio rezginio blokada be užpakalinès sąnario kapsulès infiltracinès analgezijos nesukelia pakankamos analgezijos pooperaciniu laikotarpiu, ir pacientai judesių metu jaučia didesni skausmą. Šiam teiginiui antrinama taip pat keliose randomizuotose studijose [8-11]. Bet yra teigiančiu priešingai: studijose įrodyta, jog tęstinè juosmeninio rezginio blokada pati viena yra efektyvesnè lyginant su papildomai taikoma vietine infiltracine analgezija $[12,13]$. Atsižvelgiant $i$ tai, mūsų tyrimo abiejų grupių tiriamiesiems vis dèlto buvo atlikta kelio sąnario užpakalinès kapsulès infiltracija specialiai paruoštu tirpalu.

Ali ir bendraautoriai teigia [3], intensyvus pooperacinis skausmas sumažina judesių per kelio sąnarį amplitudę, padidina analgetikų poreikị ir pailgina hospitalizacijos laiką. Taip pat teigia, kad vietinès infiltracinès analgezijos poveikis praeina per pirmają parą po PKSE operacijos, todèl tęstinè vidusąnarinè blokada yra tiesiog būtina - ji pristatoma kaip gera, saugi bei sèkminga nuskausminimo metodika.

Reinhardt ir kt. [4] savo studijoje nagrinèjo tęstinès vidusąnarinès blokados bei vienmomentès juosmeninio rezginio blokados su tęstine epidurine analgezija pašalinių poveikių pasireiškimą, analgezijos veiksmingumą bei pacientų funkcinį atsigavimą po PKSE operacijos. Deja, abiejose tirtose grupèse pašaliniai poveikiai (pykinimas, vėmimas, kraujo spaudimo svyravimas) nesiskyrè. Kelio sąnario funkcijos atsistatymas abiejose grupèse taip pat nesiskyrè nẻ viename etape. Tačiau pacientai, kuriems buvo taikyta vienmomente juosmeninio rezginio blokada su tęstine epidurine analgezija, dažniau jautė kelio linkimą ir po operacijos vèliau pradejo vaikščioti. Nors tęstinè vidusąnarinè blokada ankstyvuoju pooperaciniu laikotarpiu sąlygojo didesni skausmingumą, vis dèlto ankstyvasis kelio funkcijos atsistatymas šioje grupeje buvo greitesnis. Tačiau praejjus vieneriems metams po PKSE operacijos, abiejų grupių kelio funkcija buvo vienoda.

Norint ịvertinti, kuris nuskausminimo metodas (vietinè infiltracinè analgezija ar tęstinè juosmeninio rezginio blokada) yra efektyvesnis, Yun ir bendraautoriai [5] atliko devynių studijų metaanalizę. Remiantis ịrodymais, prieita išvados, kad pirmąsias šešias valandas po PKSE operacijos vietinè infiltracinė analgezija yra efektyvesnè. Tačiau dèl silpno įtrauktų tyrimų statistinio patikimumo, negalima formuluoti rekomendacijų, ir reikalingi tolimesni tyrimai.

Deja, daugumoje atliktų studijų yra nagrinejjami ankstyvieji rezultatai po PKSE operacijos. Informacijos apie vèlyvuosius rezultatus bei pacientų emocinès būklès įtaką 
jiems (gyvenimo kokybè, lètinis skausmas, kelio sąnario funkcija praejjus šešiems mènesiams, metams po PKSE operacijos ir pan.) trūksta [2,14-16], todèl svarias išvadas daryti yra sunku.

Ivertinus minètus faktus bei mūsų tyrimo rezultatus, galime teigti, kad tiek tęstinè juosmeninio rezginio blokada, tiek vidusąnarinè analgezija yra tinkamas pasirinkimas ūmaus skausmo po PKSE operacijos malšinimui. Tačiau pooperacinio nuskausminimo metodo itakos vèlyviesiems rezultatams vertinimui (dèl duomenų trūkumo) reikètų atlikti daugiau detalesnių tyrimų, įtraukiant ne tik daugiau pacientų, bet ir koreguojant pooperacinio sekimo protokolus (adaptuojant bei palengvinant pacientų sekimą ilgesnị laikotarpi po operacijos).

\section{Išvados}

Pooperacinio skausmo malšinimo metodas (tęstinè juosmeninio rezginio ar tęstinè vidusąnarinè blokados) po PKSE operacijos neturèjo ịtakos LS išsivystymui. Kelio sąnario funkcija tęstinès vidusąnarinès blokados grupès pacientams per pirmą ménesi po PKSE operacijos gerejjo greičiau lyginant su tęstine juosmeninio rezginio blokados grupe. Nors pooperacinị lètinị skausmą galèjo sąlygoti depresiją, abiejų grupių pacientų gyvenimo kokybė po PKSE operacijos reikšmingai pagerejjo.

\section{Literatūra}

1. Kovalak E, Doğan AT, Üzümcügil O, Obut A, Yildiz AS, Kanay E et al. A comparison of continuous femoral nerve block and periarticular local infiltration analgesia in the management of early period pain developing after total knee arthroplasty. Acta Orthop Traumatol Turc 2015;49(3):260-266.

http://dx.doi.org/10.3944/aott.2015.14.0263

2. Albrecht E, Morfey D, Chan V, Gandhi R, Koshkin A, Chin KJ et al. Single-injection or continuous femoral nerve block for total knee arthroplasty? Clin Orthop Relat Res 2014; 472:13841393.

http://dx.doi.org/10.1007/s11999-013-3192-3

3. Ali A, Sundberg M, Hansson U, Malmvik J, Flivik G. Doubtful effect of continuous intraarticular analgesia after total knee arthroplasty. Acta Orthopaedica 2015; 86 (3): 373-377.

http://dx.doi.org/10.3109/17453674.2014.991629

4. Reinhardt KR, Duggal S, Umunna BP, Reinhardt GA, Nam D, Alexiades M. et al. Intraarticular analgesia versus epidural plus femoral nerve block after TKA. Clin Orthop Relat Res 2014; 472:1400-1408.

http://dx.doi.org/10.1007/s11999-013-3351-6

5. Yun XD, Yin XL, Jiang J, Teng YJ, Dong HT, An LP. et al. Local infiltration analgesia versus femoral nerve block in total knee arthroplasty: A meta-analysis. Orthopaedics \& Traumatology: Surgery \& Research 101 2015; 565-569. http://dx.doi.org/10.1016/j.otsr.2015.03.015

6. Kao S, Lee H, Cheng C, Lin C, Tsai H. Pain control after total knee arthroplasty: comparing intra-articular local anesthetic injection with femoral nerve block. BioMed Research International 2015:649140.

http://dx.doi.org/10.1155/2015/649140

7. Chaumeron A, Audy D, Drolet P, Lavigne M, Vendittoli PA. Periarticular injection in knee arthroplasty improves quadriceps function. Clin Orthop Relat Res 2013; 471(7):2284-95.

http://dx.doi.org/10.1007/s11999-013-2928-4

8. Toftdahl K, Nikolajsen L, Haraldsted V, Madsen F, Tønnesen EK, Søballe K. Comparison of peri- and intraarticular analgesia with femoral nerve block after total knee arthroplasty: a randomized clinical trial. Acta Orthop 2007;78(2):172-9.

http://dx.doi.org/10.1080/17453670710013645

9. Ashraf A, Raut VV, Canty SJ, McLauchlan GJ. Pain control after primary total knee replacement. A prospective randomised controlled trial of local infiltration versus single shot femoral nerve block. The Knee 2013;20(5):324-7.

http://dx.doi.org/10.1016/j.knee.2013.04.009

10. Antoni M, Jenny JY, Noll E. Postoperative pain control by intraarticular local anesthesia versus femoral nerve block following total knee arthroplasty: impact on discharge. Orthop Traumatol Surg Res 2014;100(3):313-6.

http://dx.doi.org/10.1016/j.otsr.2013.12.022

11. Broome CB, Burnikel B. Novel strategies to improve early outcomes following total knee arthroplasty: a case control study of intra articular injection versus femoral nerve block. Int Orthop 2014;38(10):2087-9.

http://dx.doi.org/10.1007/s00264-014-2392-0

12. Carli F, Clemente A, Asenjo JF, Kim DJ, Mistraletti G, Gomarasca $\mathrm{M}$. et al. Analgesia and functional outcome after total knee arthroplasty: periarticular infiltration vs continuous femoral nerve block. Br J Anaesth 2010;105(2):185-95.

http://dx.doi.org/10.1093/bja/aeq112

13. Chaumeron A, Audy D, Drolet P, Lavigne M, Vendittoli PA. Periarticular injection in knee arthroplasty improves quadriceps function. Clin Orthop Relat Res 2013;471(7):2284-95. http://dx.doi.org/10.1007/s11999-013-2928-4

14. Seet E, Leong WL, Yeo AS, Fook-Chong S. Effectiveness of 3-in-1 continuous femoral block of differing concentrations compared to patient controlled intravenous morphine for post total knee arthroplasty analgesia and knee rehabilitation. Anaesth Intensive Care 2006;34(1):25-30.

15. Salinas FV, Liu SS, Mulroy MF. The effect of single-injection femoral nerve block versus continuous femoral nerve block after total knee arthroplasty on hospital length of stay and long-term functional recovery within an established clinical pathway. Anesth Analg 2006;102(4):1234-1239. http://dx.doi.org/10.1213/01.ane.0000198675.20279.81

16. Duarte VM, Fallis WM, Slonowsky D, Kwarteng K, Yeung CK. Effectiveness of femoral nerve blockade for pain control after 


\section{4}

total knee arthroplasty. J Perianesth Nurs 2006;21(5):311-316.

http://dx.doi.org/10.1016/j.jopan.2006.05.011

\section{POSTOPERATIVE PAIN CONTROL METHODS \\ INFLUENCE TO EARLY KNEE FUNCTION, CHRONIC PAIN AND QUALITY OF LIFE AFTER A TOTAL KNEE ARTHROPLASTY \\ J. Zinkus, D. Urbanaitè, A. Gelmanas, R. Tamošiūnas,} A. Vertelis, A. Macas

Key words: postoperative pain, continuous femoral nerve block, continuous intraarticular block, total knee arthroplasty, chronic pain, quality of life.

Summary

Total knee arthroplasty (TKA) is one of the most frequently performed major orthopaedic operations causing postoperative pain, which may influence quality of life. Therefore controlling the pain after these operations is a real challenge to medical staff in the whole world. Generally, multimodal analgesia is applied. However, there is still no gold standard for pain control after TKA. Our aim was to find out whether postoperative acute pain control method influences patients quality of life and the occurrence of chronic pain after TKA. The perspective study was performed. Fifty four patients who underwent TKA were included. Patients were randomized into two groups: first group (continuous femoral nerve block) and second group (continuous intraarticular block). The knee function and chronic pain influence to quality of life were evaluated by visual-analog scale, Knee injury and Osteoarthritis Outcome Score, Geriatric Depression Scale: short form. The results showed, postoperative pain control method had no influence to the occurrence of chronic pain. However, depression could cause chronic postoperative pain. The knee function recovery during the first month after TKA was faster in the second group. Despite the depression, the quality of life improved in both groups.

Correspondence to: dalia.urbanaite@gmail.com

Gauta 2016-03-17 